\title{
PECULIARITIES OF COMMUNICATION IN THE EDUCATIONAL ACTIVITY OF THE MUSEUM
}

\section{Komunikācijas īpatnības muzeja izglītojošajā darbībā}

\author{
Rita Burceva \\ Rezekne Higher Education Institution, Latvia \\ E-mail: Rita.Burceva@ru.lv
}

\begin{abstract}
One of the basic functions of a museum as a cultural institution is education of the society, satisfaction of persons' aesthetical and cognitive needs. The aim of the article is to find out what aspects of the communication process are related to maintaining the interest of the museum visitors and provision of the availability of information in its educational activity. The research has emphasized the standpoints of museum communication in relation to cooperation partners and users of museum services. The elements of communication described in the research are considered in the context of museum environment. The second part of the article is devoted to the analysis of the results of the empirical research showing the most appropriate ways of getting information for visitors and their satisfaction with the received educational and recreational services in the museum.
\end{abstract}

Keywords: communication, educational activity, museum as a cultural institution, visitors.

\section{Introduction}

"A museum is an educational and research institution available to the public, the task of which is to collect, preserve and communicate natural, tangible and intangible cultural values in the society pursuant to the specificity of operation of the museum, as well as to promote usage thereof for education and development of the society," such definition of a museum is provided in Section 7 of the "Museums Law".

The topicality of the research is determined by the condition that in theoretical literature related the issues of communication and formation and maintenance of mutual relations of organizations more attention usually is paid the internal and external communication of organizations to promote utterly the sale of products, thus gaining higher profit from sales. However, the relations of the state and local government, non-governmental organizations, educational, health and social care, cultural institutions with the society are differently oriented. They are focused on the positive public image of the organization and good reputation (e.g., intangible aspects), thus they use advertisements less, but explain more various issues and situations and educate the society.

Currently in Latvia there are over 200 institutions positioning themselves as museums. State accredited museums, e.g., the ones corresponding to definite criteria and state standards, are a bit over a half, inter alia: local government museums -84 , public museums -36 , private museums -7 (Latvijas muzeju biedrība, 2012).

The interest and perception motives and level of each museum visitor are determined by various factors - starting from general economic factors influencing 
the oportunities of local inhabitants and visitors to use museum services muzeja to personal factors determined by individual's knowledge and experience. Thus, a museum as a cultural institution shall analyze the communication policy of an organization on ongoing basis, follow its development trends to harmonize them with public insterest and offer complete educational and recreational services.

The aim of the research - to find out and analyze the peculiarities of communication of a museum as a cultural institution in its educational activity. In order to reach this aim the following tasks have been put forward:

1) to research theoretical cognitions about the essence of communication, its peculiarities and communication process relating them the educational activity of the museum,

2) to evaluate the communication process at a definite institution taking Latgale Museum of Culture and History as a basis.

The methods applied in the research:

1) exploration and analysis of theoretical literature, Internet resources, internal documents and unpublished materials of the institution in the context of the research issue,

2) providing a questionnaire to museum visitors, processing and analyzing its results.

The research is based on the cognitions of the communication, public relations and marketing specialists D.Herbst (2007), S.M.Katlips (2002), V.Praude (1994, 2005), R.Vīra (2011), T.Lapsa (2002), D.Filipss (2010) and others about the essence and forms of public relations and communication problems, conclusions of the museologists T.Ambrozs and K.Peins (2002), F.Meres (2011), R.Stevens (2001) about the aspects of the educational activity of museums as cultural institutions.

\section{Theoretical aspects of the communication process}

None of modern organizations can exist without involving into cooperation and other kind of communication with individuals, groups of persons and institutions. Communication is also very diverse activities organized by the specialists of companies and institutions to reach definite aims. Communication and interpersonal relations are among the most typical features of the modern world.

"The word "communication" (from Latin communicare - to make common, attract, talk) has many meanings. For example, in communications engineering communication is a process when a message is coded and transferred from the information source to the recipient. In daily life this word often denotes a set of means envisaged to transport something (pipes, sewage, transport, telecommunication networks, etc). Quite often this word also denotes the process of exchanging messages, thoughts and knowledge among people. In this respect communication is a kind of human action analogous to a communicative act." (Agejevs, 2005). 
In the process of mutual communication people exchange ideas, information, knowledge, views, facts, feelings, moods. In communication information is made more precise, developed and new ideas are created. In mutual communication partners try to implement their aims, interests and needs influencing each other. G.Tentere has formulated the following elements of the communication process: a source or a sender, a recipient or an addressee, contact (real communicative situation), a message, a code (language signs and symbols by which information is transferred), context or communicative environment (Tentere, 2009).

K.Kovale, L.Konstante un A.Lindemanis identify the elements of communication slightly differently (a sender, a message, a channel of communication, a recipient, feedback): "A sender - an organization or an individual preparing and disseminating information. A message - purposeful summary of information selected by the sender which is transferred to the recipient through a chosen channel of communication. A channel of communication - a carrier of information chosen by the sender ensuring delivery of a message to the recipient. A recipient - an organization or an individual receiving a message prepared by the sender. Feedback - recipient's response to the message." The effectiveness of communication can be facilitated by communicator's competence (experience, rich knowledge and skills), status, degree of reliability, etc., but specialists advise to observe the following criteria in making messages: "correspondence to the needs and interests of the audience, clarity of thought, precision (facts, information), positivism (starting with good news), layout of the message (the main information is placed in the beginning and in the end)." (Kovale, Konstante, Lindemanis, 2004)

In the context of the educational activity of the institution (specially organized acquisition of life experience) the communication process includes exchange of messages and their interpretation depending on prior information and experience of relations of both involved parties. The author is sure that there shall be considered the conditions which could impede a successful communication process: technical disorders (for example, low quality polygraphic layout impeding to perceive the message fully), semantic noises (understandability of the planned message content and one's ability to assure in the transfer process), and cognitive barriers (different understanding of some issue related to information deficit).

K.Kovale, L.Konstante and A.Lindemanis classify the groups of communicative barriers in the following way:

- "physical noise - background sounds, loud music, etc.,

- mental distraction,

- choice of inappropriate words, and resulting misunderstandings,

- lack of concentration,

- prejudices, stereotypes, negative attitude,

- inappropriate expectations,

- emotional pressure, 
- lack of observation of communication etiquette, manipulations/plays". (Kovale, Konstante, Lindemanis, 2004)

According to the author's opinion this classification of communication barriers is more suitable for oral communication than a channel of transferring a message; however, it cannot be the only one a cultural institution uses for the public educational purposes.

In the latest researches in the communication field there is emphasized the role of metamessages or metacommunication. Raina Vīra (Vīra, 2011) explains: “... you can say that metamessages are messages about messages. [...] Metamessages - it is the highest level communication about:

- the type of the message to be sent;

- the status of the message sender;

- the status of the message recipient;

- context of transferring a message."

The author thinks that in the environment of cultural and other public institutions these metamessages, which are usually related to the nonverbal behaviour of individuals, have a significant role in the establishment of interpersonal contacts and creation of the first impression.

Diving communication channels into groups I.Ezera, I.Graudina and S.Dreiberga use several approaches: by the type of communication, direction of sending information, contact with a communication partner, external form. According to the type of communication there are distinguished oral, written (resp., verbal) and nonverbal channels of communication. According to the direction of sending information there distinguished vertical (upward and downward) and horizontal or lateral channels of communication. According to the contact with a partner there is distinguished direct (audial and/or visual contact with a communication partner) and indirect communication (a communication partner is not present). According to the external form there are distinguished formal (determined by the regulated procedure) and informal (free flow of information) communication channels. (Ezera, Graudina, Dreiberga, 2000)

The positive or negative image of the organization in public to a large extent is also created by references and unofficial views exchanged by the participants of the target audiences. However, the information received from the organization or its representatives has a crucial role in the formation of background - it shall be timely, true and sufficient to prevent spreading ungrounded rumours and observe communication ethics thinking about long-term development and relations with existing and potential users of a cultural product or service as well as cooperation partners. It is significant to research public expectations and opinions to coordinate further development of the organization. The role of reflexive communication is also highlighted by S.Veinberga: "... communication can be a process during which a massage with a definite effect is sent from a sender to an addressee or it is a process during which messages and are exchanged and interpreted basing on the level of understanding of the involved parties. Up to now the first approach has 
been the most common; however, lately reflexive communication has become more popular." (Veinberga, 2004)

In communication the neutrality of a sender of information is highly appreciated as a criterion of personal responsibility as well as objectivity including balance of opinions and precision in expressions, verity. People to whom a museum specialist refers having a prepared message expect the opinions of all interested parties and unbiased facts, it can be provided only if there is unlimited access to alternative and neutral sources of information. People consider the information from a primary source to be highly truthful.

No matter how large attention shall be paid to external communication of a company (established relations with suppliers, consumers, community) some organizations insufficiently use internal communication to create their public image. Dieter Herbst asserts that internal and external communication must not contradict and employees are a mirror of the organization and "multipliers". $\mathrm{He}$ also points obstacles which might distort the flow of information:

- mistakes in retelling, perceiving, selecting and explaining information,

- procrastination of transferring information further,

- the form, content and speed of information flow can change under external impact,

- some persons, for example, chiefs, can consciously or unconsciously change information and its flow in order to hide their mistakes and drawbacks or not endanger their position and career. (Herbst, 2007)

Museum specialists are expected to have high professional skills in the field of communication: good writing skills (a lot of work is done by written communication, for example, replying to e-mails, writing press releases and invitations, creating informative and educational materials), developed oral communication skills (leading meetings and special events, participation in press conferences, giving interviews, informing company staff, guiding excursions, introducing with expositions and exhibitions, daily communication with visitors), as well as the ability to persuade and demonstrate one's competence.

If marketing and sales specialists consider selling the products of a company as the main aim, then cultural and educational institutions try "to sell" an organization as a whole maintaining its positive reputation. Seitel Fraser P. indicates that in compliance with public interest public relations are considered to be a good way how to use prior knowledge because for a public relation specialist it is crucial to feel instead of his/her planned audience to understand how they perceive the world. The experienced professional of public relations stresses that the best approach to defining public relations is viewing them as a process harmonizing long-term relations between individuals and organizations in the society: "This process includes the following five principles: 1. honest communication for credibility; 2. openness and consequence of action for reliability; 3. precise action for favourability; 4. ongoing two-way communication 
to eliminate alienation and establish relations; 5. exploration and evaluation of surrounding environment to determine action needed for social harmony." (Seitel Fraser, 1995)

Successful performance of any institution or company directly depends on its recognition, thus special attention shall be paid to explaining what strategic aims an organization has and what considerations determine direction and priorities of its performance. On the other hand, it is also essential to explore the interests, wishes of the target audience, and their general opinion about the organization to plan further activities. The lack of such emphasis does not let sufficiently use all available instruments creating communication inducing mutual trust. It would be essential to act in the way to avoid the target audience (in case of a museum existing and potential visitors) feel as a means for reaching the aims of the organization, but to let them be aware of their significance. In the communication process there shall be strong conviction that the opinion of the target group is interested in and it is essential for the respective institution.

\section{Analysis of communication peculiarities in Latgale Museum of Culture and History as a cultural institution in the aspect of its educational activity}

Latgale Museum of Culture and History is founded in 1959 as a branch of Ludza Local History Museum and it is located in a building that was a place for Central Latgale Museum until the World War II. In 1961 the museum started to work independently as Rezekne Local History Museum. Soon after, it opened its own first exposition. In 1990 Rezekne Local History Museum was renamed as Latgale Museum of Culture and History according to the nature of stock collections and contents of work. 1989 museum visitors were offered the services of a reading hall. In 1996 Rezekne City municipality assigned the three-storied building to the museum that was located next to the central museum building, thus broadening the opportunities to expose cultural heritage. (Interview with a museum pedagogue of Latgale Museum of Culture and History Inese Ločmele 02.02.2011.)

The functions of Latgale Museum of Culture and History are determined by LR Museums Law and the respective Regulations approved by Rezekne City Council in 2007 the main functions of Latgale Museum of Culture and History are as follows:

1) accumulation, documentation and preservation of tangible and intangible cultural values;

2) research of museum stock and information related to it;

3) education of the society, dissemination of tangible and intangible cultural values by creating expositions and exhibitions, involvement of visitors in various events and creating interest in regional culture, its values and traditions. (Regulations of Latgale Museum of Culture and History)

The tasks of the museum are implemented in three directions:

- $\quad$ work with stock (to supply, enlist and preserve tangible and intangible values about the history, culture, art of the city and region and Latgalian literature), 
- $\quad$ scientific research work (to research museum stock collections, organize scientific visits to archives, libraries, other museums in Latvia and abroad to research the themes related to the culture and history of the city and region, to make expositions, thematic exhibitions, art exhibitions),

- $\quad$ work with the society (basing on permanent expositions, exhibitions, museum collections to organize events corresponding to the mission of the museum, to guide excursions, to deliver lectures, to develop and lead programmes in museum pedagogy working with various age groups and target audiences, to cooperate with other cultural and educational establishments, to organize and participate in seminars, conferences, to publish books, catalogues, informative, methodological, advertising materials, to provide scientific and methodological consultations upon request within the framework of its profile to institutions, organizations and other museums and individuals). (MiddleTerm Strategy for Museum Activity)

As the aims of Latgale Museum of Culture and History are related to preservation and popularization of regional cultural and historical heritage, education of population, offering intellectual and mental recreation, interactive involvement into significant cultural events, then it rather executes public social procurement. Thus, the museum in its performance implements a visitor-friendly price policy respecting their purchasing power under changing economic conditions. There are some groups of population having free of charge visits to the museum.

The aims of Latgale Museum of Culture and History in the field of communication are not precisely defined in its development strategy; however, the author could formulate them in the following way:

1) to facilitate the identification and publicity of Latgale Museum of Culture and History applying various techniques,

2) to explore and analyze public opinions and wishes regarding the content and quality of the provided cultural and educational service as well as the wishes and recommendations of the staff to improve the performance of the organization,

3) to summarize information about topicalities in the branch using the monitoring of the mass media, databases and other public information sources to facilitate the personal growth of the staff in the branch,

4) to maintain constructive and positively oriented communication with cooperation partners for the development of the cultural institution and introduction of innovations in the museum.

Analysing the position of a definite museum in the market of similar organizations there shall be taken into consideration the mission of such type of an organization and its functions in the society. In this respect it is essential to mention the definition of the essence of a museum given by F.Meres in the article "The Tasks of a Museum vs. Economic Requirements: Avoid Violating the Limits of Compromises": “... a museum rises the prestige of a region and creates its image, strengthens social unity and facilitates education ... [...] All museums can offer their visitors aesthetical pleasure and stimuli for contemplation. A museum is in the 
crossroads of a school and a temple. In the art museum facing pieces of art a visitor feels like in a temple; a museum of history and science causes delight and purposeful wish to find out more, these museums have an educational function." (www.bms.edu.lv/resources/mairess_muz_uzd.doc)

"Latgale Museum of Culture and History exists to create the image of Rezekne as a heart of Latgale by the means of a museum and reflect its history from the dawn till nowadays, to research historical and cultural processes in Latgale, thus creating interest in the region in the society and becoming a significant tourism object," - in such a way the definition of the mission of the museum is provided in the documents regulating its activities. (Regulations of Latgale Museum of Culture and History)

Latgale Museum of Culture and History positions itself as a regional state accredited museum having typical unique expositions, exhibitions and other resources (for example, the only permanent exposition of Latgalian pottery in Latvia, a collection of works made by Latgalian old masters of painting and their followers, materials of the museum reading hall, thematic collections, etc.), thus as regards the content the aspects of competitions are not so topical as it would be, for example, in case of commercial companies oriented towards maximum sales. Thus, doubling of the services provided by the museum is practically impossible - a museum has gained its own niche among similar cultural institutions.

In the mass media and public relations activities the museum is noncommercial (just as public educational establishment, various societies, etc.). This peculiarity not only completely corresponds to the mission of the institution, but also the definition formulated by the International Council of Museums (ICOM): "A museum is a non-profit, permanent institution in the service of society and its development, open to the public, which acquires, conserves, researches, communicates and exhibits the tangible and intangible heritage of humanity and its environment for the purposes of education, study and enjoyment." (Ambrozs, Peins, 2002)

The communication aims of Latgale Museum of Culture and History are related to its identification and indicate its competence in the respective field causing the sympathies of the existing and potential visitors. By the help of appropriate means the museum tries to maintain the visitors' interest by popularizing publicly and individually significant needs facilitating emotional and cognitive growth. A majority of museum visitors are mentally mature personalities or at least the ones developing in this direction. The reports of Latgale Museum of Culture and History $(2007,2008,2009)$ contain summary of the results of the questionnaires provided to the visitors which reveal individuals' occupations and fields of interest. The author has concluded that these persons visit the museum to implement their needs for self-actualization, they have such personal features as openness to getting new experience, spontaneity in formation of their attitude, inner freedom, wish to broaden their world outlook, deepen their knowledge and understanding about some processes. Thus, Latgale Museum of Culture and History performs purposeful and systematic research of the target segment trying to 
balance supply and demand. In order to have stable development and to make strategic decisions the museum staff needs the information:

- "how well the museum competes (not only other museums are competitors, but also the whole industry of culture and entertainment),

- how the museum is perceived in the society,

- what visitors' attitude is towards the museum exhibitions, programmes, events and other products,

- how the museum could increase the number of visitors." (Stīvens, 2001)

The researcher of the museums market R. Stevens supports the thesis of J. Maccoliff that research helps museums make corrections in their activities to remove barriers and use the advantages of the institution more successfully. Research "can help a museum to decide

- whom to contact,

- where and how to contact them,

- what special offers to prepare,

- how to set a price for this offer,

- how to offer it". (Stīvens, 2001)

Latgale Museum of Culture and History successfully cooperates with state and non-governmental organizations, artists and representatives of other creative fields, scientists and researchers. The museum has a unique position in its attitude towards cultural institutions functioning in the city, region and surrounding areas it perceives them not as competitors, but as cooperation partners searching and finding common interests. In author's opinion, such attitude broadens opportunities for positive and mutually beneficial communication. Within the framework of cooperation Latgale Museum of Culture and History, for example, provides premises for partners to organize various events, partially including them into their own activities, thus broadening the target audience of the museum visitors and forming relations with potential suppliers, for example, to enrich the museum stock. It is essential to have positively oriented communication and cooperation to create a positive image of the museum. As regards the organization of events and exhibitions, the permanent cooperation partners of the museum are J.Ivanovs' Rezekne Secondary School of Music (musical accompaniment), amateur collectives of Rezekne Culture House and Rezekne County, Rezekne Secondary School of art and Design, Latgale branch of Latvian Art Academy, Latgalian Society, etc.

By questionnaires (The reports of Latgale Museum of Culture and History, 2007, 2008, 2009) Latgale Museum of Culture and History finds out visitors' opinion about the compliance of the themes of expositions and exhibitions to their wishes, their satisfaction with staff's responsiveness, topicality of museum events and other aspects creating the image of Latgale Museum of Culture and History in the society.

Public relations can facilitate the decision of potential visitors about a visit to the museum, thus for each event there is created an informative message the 
content and form of which are acceptable and understandable to the specific target audience promising to satisfy clients' interests and needs. For example, the message the museum pedagogical programme "How is Bread Made?" promises pupils to have an opportunity to take part in an improvised baking process using ancient tools, but after joint work all can have a meal at the big family table drinking herbal tea and tasting some bread. The informative message included into the booklet of the programme "Adventures of a Bit of Clay" says: "Big and small! Let's go on a wonderful trip to the kingdom of Latgale pottery feeling, smelling, hearing mysterious changes of clay! Remember, maybe on your way you will need a penny because little clay devils have definitely prepared some test." The invitation of the programme "Human Child" asserts that exactly in Latgale Museum of Culture and History you can find such thing which was used in the film of J.Streičs. The message is concluded by the words: "Come and check! Bonuks doesn't lie!" Thus, there is kept an intrigue and interest in the event.

Latgale Museum of Culture and History has dynamic activities because it is determined by various needs and interests of diverse target audiences. The public relations and advertising activities of Latgale Museum of Culture and History are planned and implemented respecting the information channels being the most available and useful for the target audience - posters, Internet resources, press, TV, radio.

All educational events organized in the museum are of equal importance; however, the extent of the public communication campaign in each individual case is determined by the specifics of the offer, forecasted peculiarities of the interests and needs of the audience, budget resources.

For example, the Museum Night is a prominent European scale event, which every year becomes more and more recognizable. Basing on the previous public relations activities Latgale Museum of Culture and History disseminates information on timely basis to give individuals more time to make a decision about coming to some event. In the beginning of a communication campaign there is provided short general information indicating the time and place of the event, further communication messages already include a detailed programme of the event, hints about possible gains. Potential visitors and the mass media base on this information planning their arrival to the event. Advertisements in newspapers are not limited just to an announcement; they also include articles about various aspects of the agenda of the event. The closer the day of the event, the more frequent and precise information is found in the media. It is done to maintain an intrigue and interest in the society. The information which appears in the media after the Museum Night is an element of the feedback in the communication process and evaluation of the event highlighting what is done and gained.

Taking into consideration the growing popularity of the Internet placing information ion this media becomes more and more topical. The information about the events in Latgale Museum of Culture and History can be obtained by those Internet users who purposefully search for it. An opportunity for a public relations specialist of the museum to use and correct information constantly is essential as 
regards the operativeness of transferring an important message, and it does not require additional investments.

The results of the questionnaires provided by the Latgale Museum of Culture and History in 2011 (in total - 89 respondents - visitors of Latgale Museum of Culture and History) show that about one third of the respondents have posters and advertisements in public places as the only channel of information where they can timely get information (see Fig.1.).

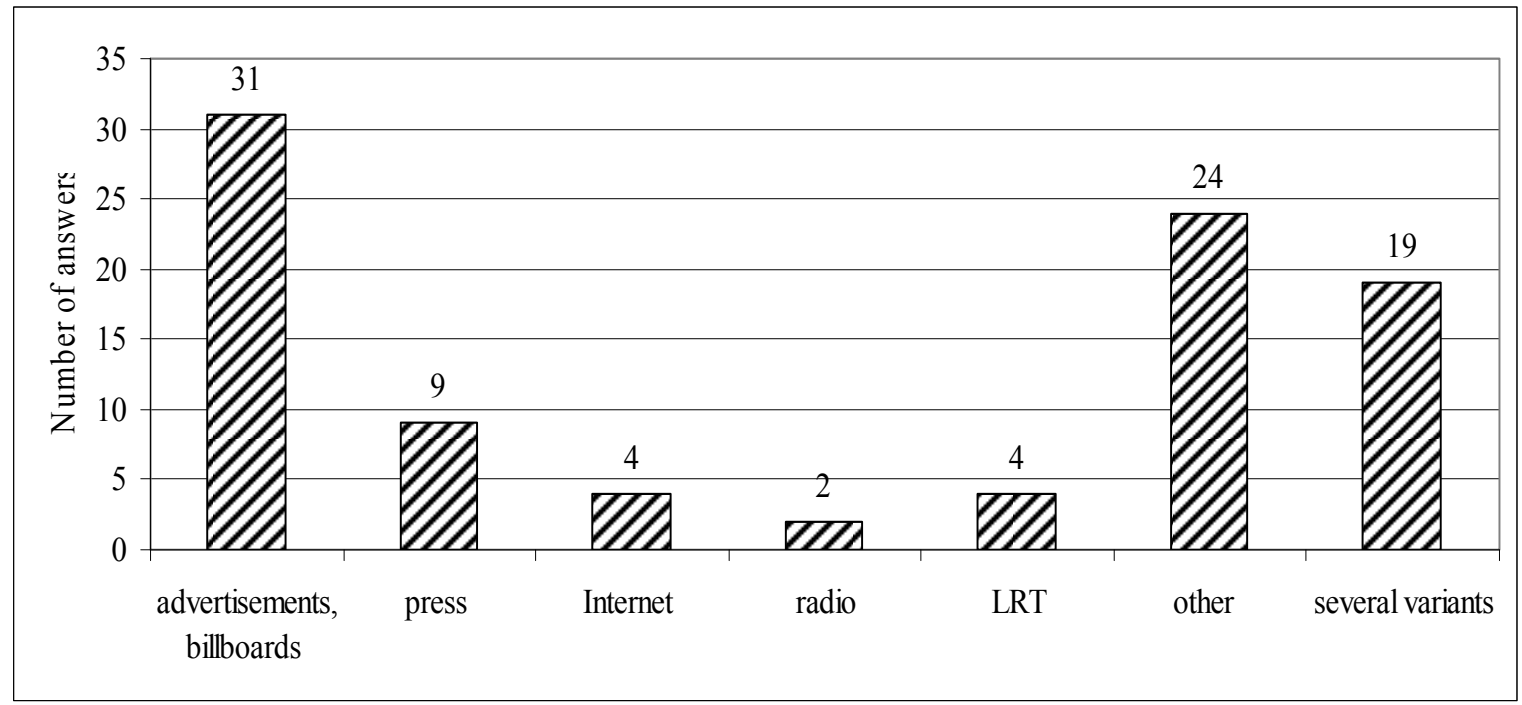

Figure 1. Sources of information about museum activities (compiled by R.Burceva)

It proves that this traditional kind of communication should not be given away although it requires greater investment of finance, labour force and time in the preparation process.

The topicality of the museum homepage is shown by the answers of the visitors to the question how respondents would like to get information about educational and artistic events taking place in the museum (see Fig.2).

Over a half of the respondents would use the museum homepage as a channel of information. These results do not contradict the previous ones; however, they indicate the trends of the modern technologies development and spreading in the modern society. 


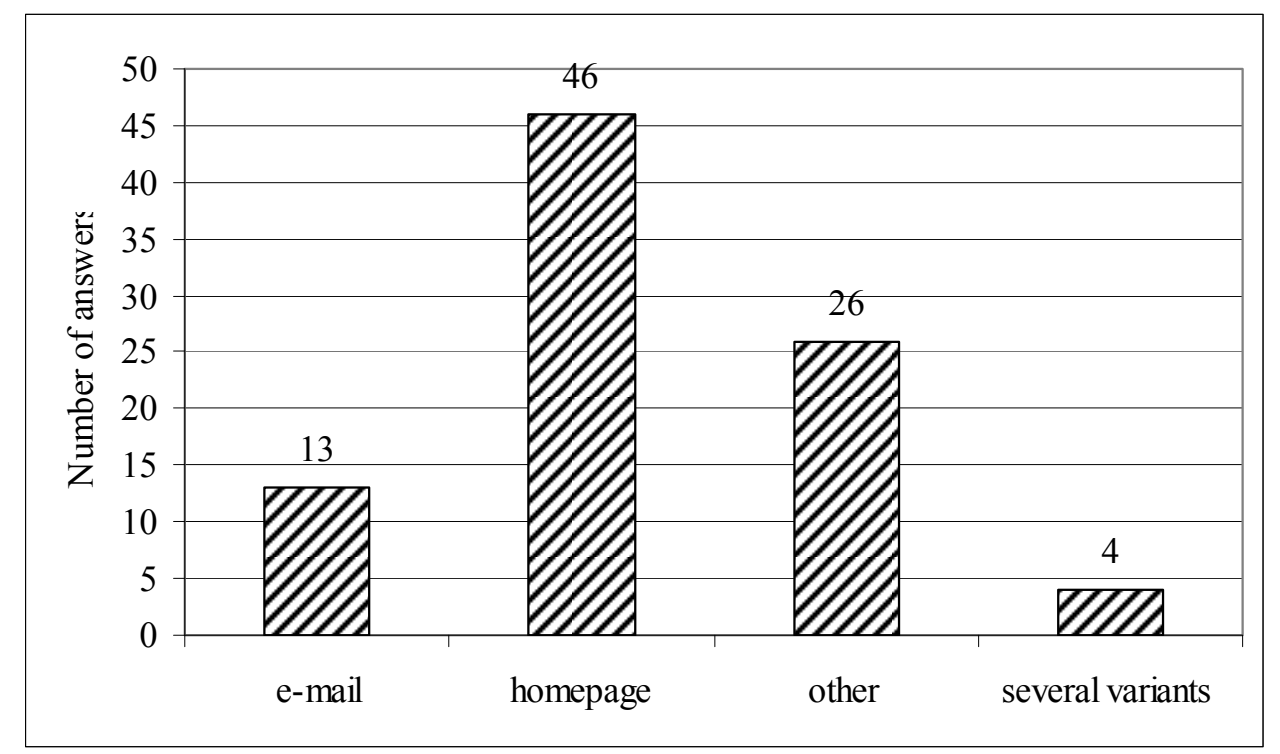

Figure 2. Preferable ways of getting information (compiled by R.Burceva)

The museum activities in educating society are supported in the form of special events, which are a significant instrument in the performance of the museum. A visit to a museum is not only a way of getting new information, but also emotional experience and an opportunity to accumulate the experience of human relations. Thus, in the museum environment it is necessary to create the messages of different content and for a diverse set of visitors, and not only a museum pedagogue and a public relations specialist work with interested visitors, but also the other staff within the limits of its professional competence. Such communication in the long-run consolidates the image of Latgale Museum of Culture and History as an individual-friendly organization.

In its performance the museum uses various measures to attract visitors. For example, special offers when groups of pupils actively attend museum events during the school year to get the promised surprise at the Museum Night. Some activities are organized as contests to encourage children and youth to involve in the event, for example, which group will wave the longest belt, etc. The winners are identified in an interactive way, for example, in a game or a quiz and they get a prize (a CD of Latgalian music records, for example, of the bands "Sovvalninks", “ Aulejas anekdoti", "Cyblas meiklis", etc.). Some programmes include degustation, practical activities, which arouse interest and willingness to participate (for example, making Christmas decorations on the Family Day), etc. and it causes positive emotions. Another example - in order to take part in the prize lottery one shall get introduced with all indicated points in the expositions during the Museum Night. Consulting occasional or regular museum visitors on the current or planned events requires a flexible approach providing an opportunity to apply the methods of making interested in something, assuring and involving, thus orienting visitors to a dialogue and mutual cooperation.

The questionnaires of the museum visitors provide an opportunity not only to establish facts, become aware of public opinion, but also plan further public 
relations activities choosing the appropriate forms and style of communication, living along with the events and flexibly adjusting to changes in the structure of visitors' wishes and needs.

The demographic data of the persons involved in the questionnaire offered by the author are summarized in Figure 3.

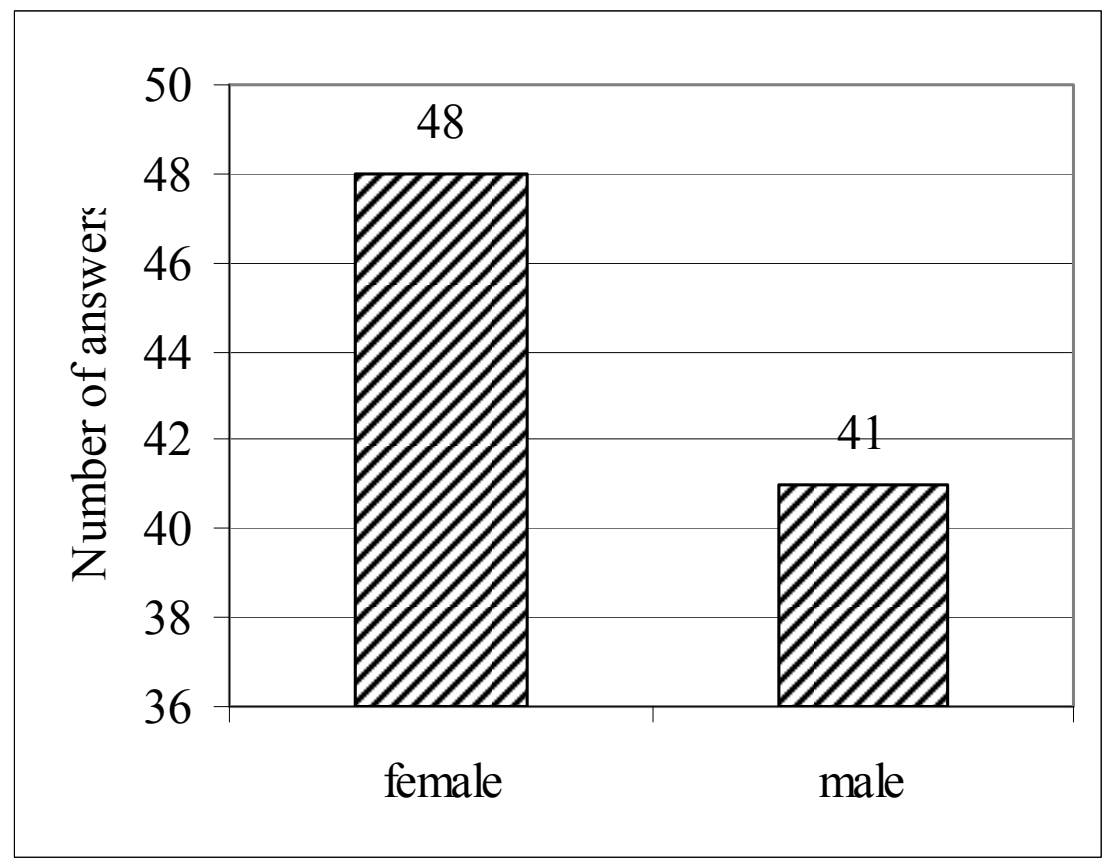

Figure 3. Respondents' gender (compiled by R.Burceva)

Females are more active participants of museum events and more willing to participate in questionnaires and other researches where they need to express their opinion. Different social activity is also demonstrated among the age groups of museum visitors (see Fig.4).

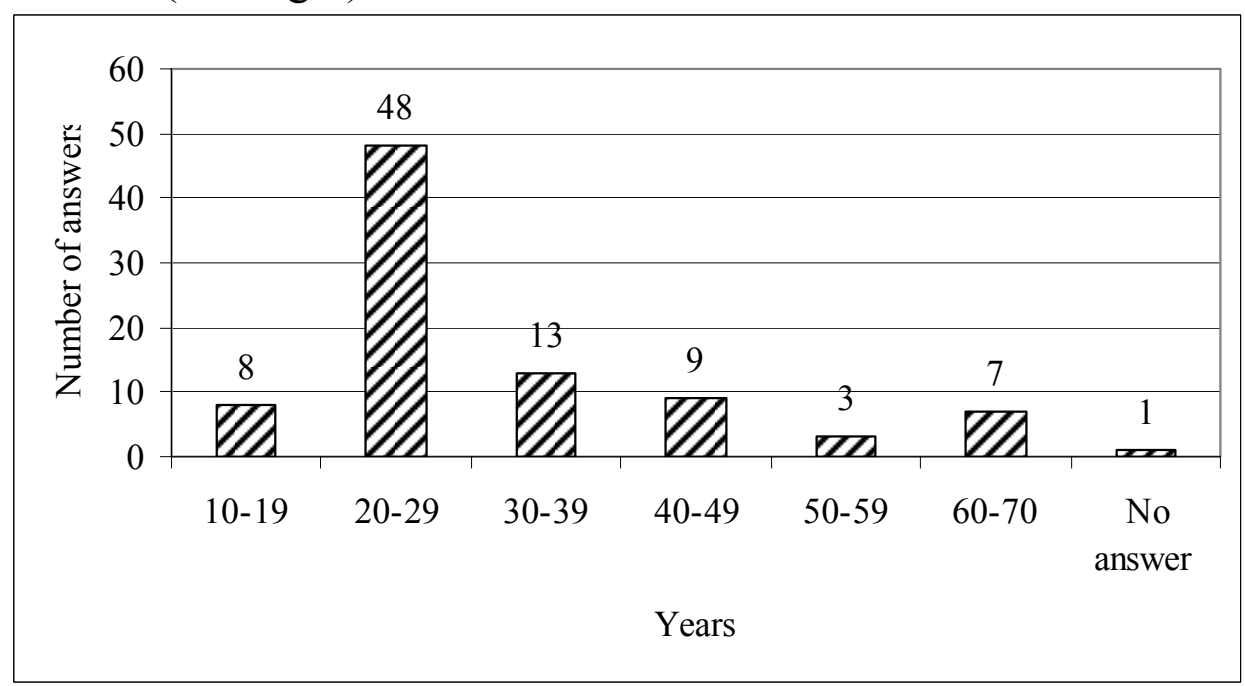

Figure 4. Respondents' age (compiled by R.Burceva)

The data demonstrate a majority of the youth are in the age group 20 to 29 years. It means that in this age group, for whom it is a topical opportunity to get 
new experience (for educational or personal purposes), respondents are open and willing to participate in events. However, it shall be taken into consideration that these data do not lead to a conclusion that in general out of all museum visitors always approximately a half is the youth exactly in this age group. The obtained data partially prove the observations of the previous years that pupils and youth in the age up to 30 years and people at the pre-retirement and retirement age are among the most active museum visitors. The first ones often to the museum encouraged by their teachers or by their accompaniment; however, the individuals of the second are at such age when their career and work approach to the end and they shall find new opportunities for spending their free time. Thus, the museum shall think about new offers to these target audiences. The style and kind of the message shall differ in communication with individuals of various age groups. The information addressed to the youth shall be in a more expressive form.

There is an unchanging tendency in the development of the museum, for example, not only the increase of the total number of visitors, bet also the increase of the visitors who have come here for the first time. It means that in communication with visitors the museum staff shall take into consideration their prior experience when forming relations with these individuals, e.g., maybe deeper information about the issue they are interested in, basic facts about the museum, expositions, stock, exhibitions, resources of the reading hall, etc. will be needed. For this reason the museum staff shall prepare compact, laconic handouts if there is no opportunity to pay attention to a specific visitor for a long time. However, at the same time the staff shall observe if visitors' questions are answered and the first impression about the museum is positive. In order to satisfy the interests of regular visitors sometimes the specialists from the Art Department or the museum reading hall shall be invited. Thus, the museum persons on duty and guards of the exhibition hall shall be well informed about the limits of other staff competence and opportunities to solve problem situations.

The next question of the questionnaire is addressed to the visitors of the museum, who have been in the museum for more than one time. The question is when the museum visitor has been here previous time. The aim of the question is to get an approximate view about the role of the museum in the range of visitor's interests. The results are depicted in Figure 5.

Comparing the received answers about the plan of museum activities the administration of the museum can conclude which events have addressed the potential visitors and what instruments of public relations have been effective influencing consumer behaviour.

None negative answer was provided in the question about the satisfaction with the working hours of the museum, ticket prices, attitude of the staff and the museum in general. 


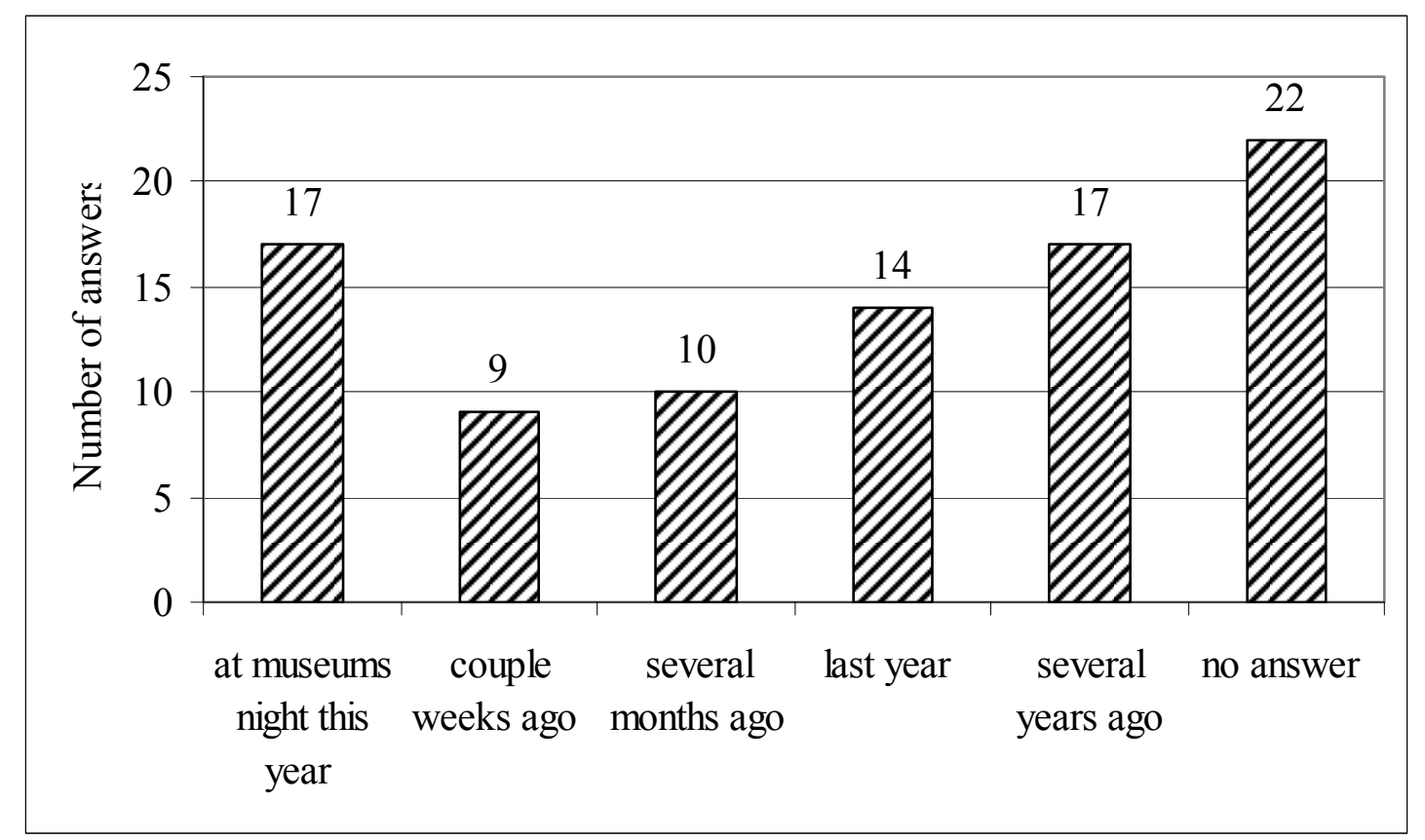

Figure 5. Respondents' answers to the question about a previous visit to the museum (compiled by R.Burceva)

The visitors have expressed greater satisfaction with the price policy if museum services and the museum in general, $10 \%$ are not satisfied with the working hours of the museum, although it has been adjusted according to the results of previous questionnaires and $9 \%$ of visitors would like better service. It is possible that the individuals dissatisfied with working hours have come on Monday, when the museum is closed to visitors, but the staff has its everyday duties. Visitors are explained when exhibitions are opened and they are invited to meet in the museum events. When communicating with visitors it is essential to keep a mutually honourable attitude typical for cultural institutions and their visitors to leave good impression and facilitate further cooperation. Besides, it shall be analyzed what could be the reasons for visitors' dissatisfaction with service in the museum - whether it is the incompetence of the staff, lack of attention or visitor's bad mood, etc.

\section{Conclusions and suggestions}

1. The activity of Latgale Museum of Culture and History in the field of educating the society mostly is based on a two-way communication model envisaging an opportunity to get feedback. Communication in the educational activity of the museum can be direct or indirect, formal or informal.

2. The most significant peculiarities of communication in Latgale Museum of Culture and History are as follows:

- work with the society as one of the major fields;

- introducing interactive and modern forms of work there shall be changed the stereotype of visitors that a museum is a conservative institution; 
- the basic aim for the application of all means of communication is education of individuals and heritage of traditions; ethical and positively-oriented communication (not to stain competitors, but find cooperation partners);

- not only administration, but also all members of the staff communicate with the society.

3. The results of the questionnaire show that approximately a third of the respondents have posters and advertisements in public places as the only channel where they constantly gain timely information, thus this channel of written communication shall be preserved. Over a half of the respondents would like to use the homepage of the museum as a channel of information. Such homepage is needed for a respectable public cultural institution nowadays.

4. The educational activity of the museum as a cultural institution is a complex phenomenon requiring a professional approach to communication in an organization, application of information transfer channels, researches of the needs and interests of the target audience.

5. The new development strategy of Latgale Museum of Culture and History, which will be adopted in 2012, shall include standpoints about further development of the existing expositions and programmes extending the variety of events and searching for creative and progressive solutions of the communication process (new information transfer channels, interactive forms of work, use of social networks) in the existing cooperation with interested partners, thus broadening the opportunities to satisfy the needs of the society to spend free time and have cognitive interest. It would be the grounds for the museum to show itself as a developing and growth-oriented organization.

6. Latgale Museum of Culture and History shall create its own homepage, where there is provided all information about its activities in the same place. Creation and maintenance of the homepage as well as the management of information and visual material renewal shall be taken by a specialist of public relations, but other staff: an artist, a preserver of the museum stock, a photographer, a museum pedagogue, etc. shall be involved to create materials. The existence of the homepage would make it easier to find topical information for the interested persons.

\section{Bibliography}

1. Agejevs V. (2005) Semiotika. R.: Jumava.

2. Ambrozs T., Peins K. (2002) Muzeju darbības pamati. R.: Muzeju valsts pārvalde.

3. Belčcikovs J., Praude V. (1994) Mārketings. R.: Zvaigzne ABC.

4. Herbsts D. (2007) Komunikācija uzñēmumā. Profesionāḷa 1x1. R.: Zvaigzne ABC.

5. Katlips S.M., Senters A.H., Brūms G.M. (2002) Sabiedriskās attiecības. R.: Avots.

6. Kovale K., Konstante L., Lindemanis A. (2004) Kā veidot komunikācijas kampaņu? Rokasgrāmata. R.: ANO Attīstības programma Latvijā.

7. Lapsa T. (2002) Sabiedriskās attiecības: ievads teorijā un praksē. R.: Biznesa augstskola „Turība” 
8. Latvijas muzeju biedrïba http://www.muzeji.lv/lv/info/about/frequently-asked-questions (sk. 26.02.2012.)

9. LR Muzeju likums [Museums Law], spēkā ar 17.01.2006.// Latvijas Vēstnesis. - Nr.1 (3369), 03.01.2006., ar grozijumiem 15.12.2009. http://www.likumi.lv/doc (sk. 04.03.2012.)

10. Praude V. [b.g.] Mārketings: teorija un prakse. 2.grāmata. R.: Burtene.

11. Praude V., Šalkovska (2005) J. Mārketinga komunikācijas: teorija un prakse. R.: Vaidelote.

12. Seitel Fraser P. (1995) The Practice of Public Relations. 5th edition. New York: Macmillian Publishing Company.

13. Stīvens R. (2001) Latvijas muzeju tirgus izpēte. Rokasgrāmata. R.: Muzeju valsts pārvalde.

14. Tentere G. (2009) Žurnālistikas pamati. R.: BVK.

15. Veinberga S. (2004) Publiskās attiecības PR. Teorija un prakse. R.: Zvaigzne ABC.

16. Vīra R. Metavēstījumi komunikācijā. http://www.turiba.lv/komunikacijas_2009/pages/Vira_lv.html (sk.16.11.2011.)

17. Intervija ar Latgales kultūrvēstures muzeja mākslinieci Inesi Dunduri 02.02.2011. [Interview with an artist of Latgale Museum of Culture and History Inese Dundure 02.02.2011. ]

18. Intervija ar Latgales kultūrvēstures muzeja muzejpedagoği Inesi Ločmeli 02.02.2011. [Interview with a museum pedagogue of Latgale Museum of Culture and History Inese Ločmele 02.02.2011.]

19. Latgales kultūrvēstures muzeja nolikums [Regulations of Latgale Museum of Culture and History]

20. Latgales kultūrvēstures muzejs. Gada pārskats. 2007.g. [Latgale Museum of Culture and History. Annual report. 2007.]

21. Latgales kultūrvēstures muzejs. Gada pārskats. 2008.g. [Latgale Museum of Culture and History. Annual report. 2008.]

22. Latgales kultūrvēstures muzejs. Gada pārskats. 2009.g. [Latgale Museum of Culture and History. Annual report. 2009.]

23. Vidēja termiņa muzeja darbības stratēgija (2007-2011) [Middle-Term Strategy for Museum Activity (2007-2011) ]

24. Vizuālie materiāli par LKM (bukleti, skrejlapas, ielūgumi) [Visual materials about Latgale Museum of Culture and History (booklets, leaflets, invitations)]

\begin{tabular}{|ll|}
\hline Rita Burceva & Rezekne Higher Education Institution \\
& Atbrivosanas al.115, Rezekne, LV-4601, Latvia \\
& E-mail: Rita.Burceva@ru.lv \\
\hline
\end{tabular}

